\title{
Teaching The Writing Process As A First And Second Language Revisited: Are They The Same?
}

Felicia Lincoln, University of Arkansas, USA

Anisa Ben Idris, University of Arkansas, USA

\begin{abstract}
Research on the second writing process is not recent. Both first and second writing processes have been in the area of argument among scholars. It has been confirmed that both first and second writers nearly all practice similar physical activities pre-writing, during, and post writing stages; however, they still differ in the inner extra thinking activities that non-native writers practice to reduce the transfer of first language rules during the writing processes. Therefore, teachers should provide extensive feedback to ELL students to help them improve their writing skills (Brown, 2007; Dyer, 1996; Ferris, 2002; Hyland, 2003; Krashen, 1982; Silva, 1997).
\end{abstract}

Keywords: Process Approach For Teaching Writing; ELL Students; Error Treatment Process

\section{INTRODUCTION}

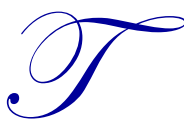

he application of the process approach to teaching writing as a second language is affected by teachers' instructional strategies that reflect "their underlying philosophy of teaching" (Kroll, 2001, p. 219). Writing skills as a process is similar whether it is English students or English language learners (ELL). This paper is an overview describing the process approach as a methodology for teaching native and ELL writing students. It focuses on both similarities between the writing process as a first and second language (Zamel, 1982) and differences. There are those who see the two groups of students as using different processes due to the cognitive and mental efforts that ELL students practice during writing. Therefore, teachers who think this process is different argue that teachers should be selective-treating ELL students' errors to help them improve their writing skills (Bates, Lane \&Lange, 1993; Ferris, 2002; Guénette, 2012; McMartin-Miller, 2014; Silva, 1997).

\section{Process Approach For Teaching Writing As A First Language}

Initially, the process approach was proposed for teaching first language composition in the eighties as a reaction to the controlled composition approach which focused on teaching structures to build writing ability through habit formation. In the controlled composition, teachers' roles were to provide a collection of linguistic structures while students were only manipulators of these structures (Silva, 1990). The process approach opposed the teaching techniques that were inherited from behaviorism, such as substitute tables, dictation, and repeating writing specific models all of which controlled classroom practices for a while (Paulston, 1972; Silva, 1990). Two main movements dominated the application of the process approach as a first language writing tool. Each movement focused on teaching one part of the writing process either as performance in expressive movement proponents or as competence in the cognitive movement camp (Johns, 1990; Krashen, 1984). First, the expressive movement supporters viewed writing as a nondirective act that aims at self-discovery and encourages students to write journals and personal essays to enhance their writing skills (Johns, 1990). Murray (1972) emphasized that mechanisms are the last step that teachers should correct because correcting them in the early stage hinders students from involving themselves in the writing process. Instead they should be allowed to write to convey meaning and express what they want to say. Also, they believed that students should be evaluated on the basis of the final draft, such as judging the 
pianist on his performance and not on how many hours he spends on training. On the other hand, the cognitive movement viewed teaching writing skills as a process of problem-solving which contains two parts - thinking and process. The thinking part takes place in the pre-writing stage where higher-order thinking skills, such as "defining the rhetorical problem, placing it in a larger context, making it operational, exploring its parts, generating alternatives solutions, and arriving at a well-supported conclusion", take place (Johns, 1990, p. 26). The second part of the writing process focuses on the actual writing process that requires students to interpret all the thoughts that they constructed in the pre-writing stage into the final written product.

\section{Process Approach For Teaching Writing As A Second Language}

On the other hand, the debate about teaching ELL writing as a process in the eighties and nineties could be described as the shift from what to teach in writing classes to how to teach in writing classes. The discussion began to establish a clear comprehensive view of teaching writing as a separate skill. A huge debate took place among scholars, such as Zamel (1982), Krahnke et al. (1983), Krashen (1984), and Raimes (1983). Zamel (1982), who stated that the writing behavior of both native and ELL writers is similar in that they use the same strategies to express their ideas, they get started by expressing general ideas, writing a first draft, and editing a final composition. The discussion centered around whether teaching writing to native speakers is the same or similar to teaching nonnative speakers. This debate reflected the start of an awareness that the writing skill is a process. In a sense, if teachers follow the same process as native writers, this will help them to better teach writing skills to non-native speakers. Similarly, Krahnke and Christison (1983) argued that there is a need to focus on how to teach instead of teaching students ready-made forms and structures which make them passive learners. Raimes (1983) stressed that writing teachers should focus on teaching writing as a process and on how to convey meaning, construct forms, and select vocabulary. There was a consensus that language is not only forms and vocabulary - it is linked by thoughts. Therefore, the process approach used in teaching composition to native speakers was utilized as a methodology for teaching ELL writing (Silva, 1990). The teacher's role became not only editing and correcting errors; instead, it shifted mainly to helping students develop their writing skills in pre, during and post writing stages.

\section{The Nature Of First And Second Learner's Errors In The Process Approach}

The assumption that writing behaviors of both native and ELL writers are similar (Zamel, 1982) seems to be an oversimplification of the writing process. It focuses on the writing process as a physical activity and ignores the learning condition that affects the implication of error treatment that both ELL and native speakers need (Brown, 2007; Dyer, 1996; Ferris, 2002; Hyland, 2003; Krashen, 1982; Silva, 1997).

The writing processes in native and second language learners are similar as a physical activity that goes through various stages - brainstorming, writing a first draft, and editing a final product. At the same time, they differ as a mental activity that requires non-native writers to engage in extra efforts when they want to express, argue, or discuss thoughts and concepts in a second language (Brown, 2007).

It is important that teachers differentiate between the mental efforts that distinguish between native and non-native writers so that they do not overlap feedback techniques between two different situations in teaching writing as a first language (L1) and as a second language (Brown, 2007; Ferris, 2004; Ferris, 2014; Silva, 1993). For example, Silva (1993) examined 72 empirical reports that compared the writing process as a first and second language. The results showed that although the writing process is somewhat similar in their physical components, there were some differences in the features of "the sub-process: planning, transcribing, and reviewing" (p. 657) as well as in the features of the produced texts - "fluency, accuracy, [quality], and structure" (p. 657). Therefore, this overlapping in some research has made writing teachers and educators expect somewhat similar progress by adopting similar writing instructional strategies whether in implementing the writing process or treating students' errors (Dyer, 1996; Ferris, 2002; Silva, 1993).

Dealing with ELL students' errors requires teachers to understand differences between common errors that ELLs make and errors in writing that native students make during the writing process (Dyer, 1996; Ferris, 2002). Although native students have intuitions about using grammatical rules and structure, they may have errors such as "punctuation rules, pronoun references, and informal usage in their academic writing" (Ferris, 2002, p. 51). On the 
other hand, ELL students have errors as a result of lacking the linguistic knowledge of the target language; they make errors on various linguistic levels - for example, misusing grammatical tenses, articles, sentence structure, idioms, and punctuation (Ferris, 2002). Even if these grammatical structures were taught explicitly to these students, mastering them would not guarantee that ELLs would achieve the automatic proficiency of native speakers. Native speakers use their intuition of linguistic knowledge effectively without attending to it that imposes cognitive efforts during writing as ELL students (Francis, Romo, \& Gelman, 2002). In addition to the level of language proficiency, ELL students make various types of errors as a result of the first language (L1) influence and cultural background (Dyer, 1996; Ferris, 2002; Silva, 1997).

ELL students need different error treatments that differ in the type of input; therefore, ELL students need to receive error treatment that aims to develop conscious knowledge of the target language rules.

\section{Treating EL Learner's Errors In The Process Approach}

For more than two decades, scholars and educators have asserted that ELLs learners need input (Krashen, 1982) as well as output to develop (Canale \& Swain, 1980; Swain, 2000) their writing competence and improve their performance. However, whether that input as a process should treat students' inaccuracies or not remained an area of argument among scholars (Ferris, 2002; Guénette, 2012; McMartin-Miller, 2014). Ferris (2002) provided literature that represents these opposing views and she asserts that treating students' errors is a necessary step that teachers should provide to help develop ELL students' writing skills and "overall second language acquisition" (p.49). Treating ELL students' errors should aim to develop students' conscious knowledge about their errors and engaging them in the treatment process as active participants (Ferris, 2002; Ferris, Liu, Sinha, \& Senna, 2013; Kepner, 1991; McMartin-Miller, 2014). To make teachers' feedback helpful in treating students' errors, teachers need to know the mechanisms of treating errors - what type of errors should be addressed during the writing process as well as how to treat them (Ferris, 2002).

\section{Types Of Errors}

Basically, in the process approach, ELL students' errors are seen as an important stage in developing the writing skills because they are a sign of processing information through using cognitive strategies. Therefore, providing error feedback is very important to help ELL students improve their writing skills and avoid fossilization (Ferris, 2004) that happens as a result of over-generalizing and "hypothesizing false concepts" (Kroll \& Schafer, 1978, p. 243). Teachers should not deal with all ELL errors at once. Instead, teachers should be selective in responding to students' errors (Bates, Lane, \& Lange, 1993; Ellis, Sheen, Murakami \& Takashima, 2008; Ferris, 2002; McMartin-Miller, 2014). Selecting which errors to focus on while providing feedback should be based on three aspects - prioritizing error types, alignment between class discussion and students' individual errors, and frequently produced errors (Ferris, 2002).

Ferris (2002) suggests that teachers need to make choices about the error treatment process, and these choices should be made on the principle of prioritizing students' errors through three bases. First, teachers should prioritize treating students' errors by distinguishing between global and local errors. As explained by Bates, Lane, and Lange (1993), Ferris (2002), and McMartin-Miller (2014), global errors are those that hinder understanding of what ESL students want to convey to their readers. For example, some lexical choices and grammatical structures that are used by ELL students make readers either think of a meaning that was not intended by students that stop readers completely from comprehending writers' messages. On the other hand, local errors are incorrect linguistic structures that are not perfectly clear to readers, but they do not prevent readers from understanding the students' writing. Also, Ferris (2002) emphasized making an alignment between major errors discussed for assignments and students' individual errors as another aspect that helps teachers decide which errors to highlight during the error treatment process. For example, before asking students to use various verb tenses as a part of writing a biography, teachers must discuss with them how changes in verb tense will affect what writers need to express. The last aspect is focusing on frequent errors that ELL students' produce during writing. By recognizing repetitive errors, teachers can individualize error treatment and follow students' writing improvement. As stated by Segalowitz and Trofimovich (2012), "learners' performance reflects the language input they can effectively use at a given stage of development" (p. 181). Therefore, frequent errors are a sign of an information gap between students' linguistic 
competence and their performance. For example, misusing articles and verb tenses are common errors among ESL students, although these topics are frequently discussed in the basic stage of learning English (Ferris, 2002). Teachers can track students' errors by using "individualized error analyses" (p.58) from students' previous written materials, such as a questionnaire and pretest at the beginning of the course. Also, scanning through students' written products is another strategy that teachers can use to locate repetitive errors and follow students' progress during the course.

As an initial step for treating ESL students' errors in writing, teachers should be selective in treating ESL students' errors. First, teachers should focus on errors that prevent students from conveying ideas and expressing themselves. Later, after students develop clear ideas about what they want to express, teachers can direct students' attention to correct linguistic structures by explaining individual errors within the framework of general errors discussed in class.

\section{Mechanism Of Treating ELL Errors}

Having recognized general errors in writing that ELLs make, teachers arrive at a place where they want to help students overcome these errors. Researchers have suggested that when ELL teachers want to choose the right way for providing feedback, they must be careful about which approach to adopt (Ferris, 2002; Guénette, 2012; McMartin-Miller, 2014) regarding the type and time of feedback (Ferris, 2002).

Providing feedback can be done either directly or indirectly. In direct feedback, teachers are information "providers" (Guénette, 2012, p. 121). Teachers treat ELL students' errors by correcting them in the text and giving direct suggestions about the right linguistic structure (Ferris, 2002; Guénette, 2012; McMartin-Miller, 2014). Then students respond to teachers' suggestions in a new draft. The direct approach is suitable for teaching ELL students who are still developing their linguistic knowledge. Teachers' direct correction will help students focus on problems in their writings because if teachers left error treatment to the end, students would not recognize them. On the other hand, in indirect feedback, teachers refer to errors' location by indicating that there is an error without giving explicit suggestions for corrections. Teachers use various techniques to indicate errors indirectly (Ferris, 2002; Guénette, 2012; McMartin-Miller, 2014) such as referring to the error's location, providing a comment at the end of the text, and identifying only error type through providing a code or verbal cue (Ferris, 2002). The indirect feedback approach is the most commonly recommended method for responding to students' errors when ESL students have a linguistic background. The advantage of using indirect feedback is that teachers become more than a direct provider of correction. Instead, the teacher's role is an "initiator" (Guénette, 2012, p. 121) that helps ELL students think independently and try to figure out how to correct errors based on information provided by teachers (Ferris, 2002; Guénette, 2012; McMartin-Miller, 2014).

Timing of feedback is another important aspect that teachers should take into account when they respond to ELL students' errors (Ferris, 2002). It is suggested that providing extensive feedback either directly or indirectly in students' first drafts will not help them develop their writing skills because it "may short-circuit students' ability to think, compose, and revise their content" during the brainstorming process (p.61). This view is consistent with Krashen's (1984) explanation of writing problems among ELL students. Krashen (1984) divided ELL writing problems into two types - remedial writers and blocked writers. A remedial writer refers to language learners who lack the principles of written competence, and that is reflected in their inefficient performance. The second is a blocked writer - a learner who developed the linguistic code but applies the composing process inefficiently because they overuse the learned grammatical rules in every stage in writing, which blocks their thinking about what they want to say. They limit themselves only to the form without paying attention to the meaning. On the contrary, refraining completely from providing feedback during brainstorming ideas (Ferris, 2002) and writing multiple drafts may lead students to continue producing serious errors that hinder communication (Guénette, 2012). Thus, teachers need to take a middle approach that deals with global and some organizational errors in the first stages of the writing process, such as errors in paragraph organization. Also, teachers should involve ESL students in a self-editing process to correct errors, such as punctuation and surface linguistic, that do not block understanding students' messages (Ferris, 2002; Guénette, 2012). 


\section{CONCLUSION}

Teaching writing skills to second language learners as a process is somewhat similar to first language behaviors. As a physical practice, both require writers to think, write and revise their writings (Zamel, 1982). However, teaching writing as a skill is more than just physical conscious activities practiced as pre, during, and post writing stages, with the most important part of the process approach for teaching ELL students being the unconscious process that puts mental efforts on ESL writers to go back and forth from classifying meanings to expressing thoughts in a second language (Brown, 2007). These unconscious processes are affected by differences in discourse between the native culture and the second culture, as well as the level of proficiency in the second language (Silva, 1997). Thus, teachers need to be aware of these major differences between the writing processes that first and second language students use during writing. These differences require teachers to adopt a particular treatment process for each learner to help ELL students develop their writing skills (Bates, Lane, \& Lange, 1993; Ferris, 2002, Guénette, 2012; McMartin-Miller, 2014; Silva, 1997).

\section{AUTHOR INFORMATION}

Felicia Lincoln is an associate professor of ELL education at the University of Arkansas. Her research interests are public school language minority education and ELL pedagogy and second language acquisition. She has published many articles in professional refereed journals.

Anisa Ben Idris is a Ph.D. student in the Curriculum and Instruction Department at the University of Arkansas. Her research interests are ELL pedagogy and second language acquisition.

\section{REFERENCES}

Bates, L., Lane, J., \& Lange, E. (1993). Writing clearly: Responding to ESL compositions. Boston, MA: Heinle and Heinle.

Brown, D. (2007). Principles of language learning and teaching. New York: Pearson Education.

Canale, M., \& Swain, M. (1980). Theoretical bases of communicative approaches to second language teaching and testing. Applied Linguistics, 1(1), 1-47.

Dyer, B. (1996). L1 and 2 L composition theories: Hillocks' 'environmental mode' and task-based language teaching. ELT, 321-317.

Ellis, R., Sheen, Y., Murakami, M., \& Takashima, H. (2008). The effects of focused and unfocused written corrective feedback in an English as a foreign language context. System, 36(3), 353-371.

Ferris, D. (2002). Treatment of error in second language student writing. University of Michigan Press.

Ferris, D. (2004). The grammar correction debate in second language writing: Where are we, and where do we go from here? (and what do we do in the meantime ...?). Journal of Second Language Writing, 3, 49-62.

Ferris, D. (2014). Responding to student writing: Teachers' philosophies and practices. Assessing Writing, 19, 6-23.

Ferris, D., Liu, H., Sinha, A., \& Senna, M. (2013). Written corrective feedback for individual L2 writers. Journal of Second Language Writing, 22(3), 307-329.

Francis, W., Romo, L., \& Gelman, R. (2002). 14 Syntactic structure, grammatical accuracy, and content in secondlanguage writing: An analysis of skill learning and on-line processing. Advances in Psychology, 134, $317-$ 337.

Guénette, D. (2012). The pedagogy of error correction: Surviving the written corrective feedback challenge. TESL Canada Journal, 30(1), 117-126.

Hyland, K. (2003). Genre-based pedagogies: A social response to process. Journal of second language writing, $12(1), 17-29$.

Johns, A. (1990). L1 composition theories: Implications for developing theories of L2 composition. In B. Kroll (Ed.), Second language writing research: Research insights for the classroom. (pp. 11-23). Cambridge: Cambridge University Press.

Kepner, C. (1991). An experiment in the relationship of types of written feedback to the development of second-language writing skills. The Modern Language Journal, 75(3), 305-313.

Krahnke, K., \& Christison, M. (1983). Recent language research and some language teaching principles. Tesol Quarterly, 17(4), 625-649. 
Krashen, S. (1982). Principles and practice in second language acquisition. Oxford: Pergamon Press.

Krashen, S. (1984). Writing research theory and applications. Oxford: Pergamon Press.

Kroll, B. (2001). Considerations for teaching an ESL/ EFL writing and going just beyond. In M. Celce-Murcia (Ed.), Teaching English as a second or foreign language (pp. 219-232). Boston: Heinle, Cengage Learning.

Kroll, B., \& Schafer, J. (1978). Error-analysis and the teaching of composition. College Composition and Communication, 29 (3), 242-248.

McMartin-Miller, C. (2014). How much feedback is enough? Instructor practices and student attitudes toward error treatment in second language writing. Assessing Writing, 19, 24-35.

Murray, D. (1972). Teach writing as a process not product. The Leaflet, 71(3), 11-14.

Paulston, C. (1972). Teaching writing in the ESOL classroom: Techniques of controlled composition. TESOL Quarterly, V6, 1, 33-59.

Raimes, A. (1983). Tradition and revolution in ESL teaching. TESOL Quarterly, 17(4), 535-552.

Segalowitzm, N., \& Trofimovich, P. (2012). Second language acquisition processing. In Susan, Gass \& M, Alison (Eds). The Routledge handbook of second language acquisition. (pp.179-192). New York, NY: Routledge.

Silva, T. (1990). Second language composition instruction: developments, issues, and directions in ESL. In B. Kroll (Ed.), Second language writing research: Research insights for the classroom. (pp. 11-23). Cambridge: Cambridge University Press.

Silva, T. (1993). Toward an understanding of the distinct nature of L2 writing: The ESL research and its implications. TESOL Quarterly, 27(4), 657-677.

Silva, T. (1997). On the ethical treatment of ESL writers. TESOL quarterly, 31(2), 359-363.

Swain, M. (2000). The output hypothesis and beyond: Mediating acquisition through collaborative dialogue. Sociocultural Theory and Second Language Learning, 97, 114.

Zamel, V. (1982). Writing: the process of discovering meaning. TESOL Quarterly. 16, 195-209. 